\title{
Evaluating the Importance of Stem Canker of Soybean in Iowa
}

\author{
X. Lu, A. E. Robertson, E. Z. Byamukama, and F. W. Nutter, Jr., Department of Plant Pathology, Iowa State Uni- \\ versity, Ames 50011
}

\begin{abstract}
Lu, X., Robertson, A. E., Byamukama, E. Z., and Nutter, F. W., Jr. 2010. Evaluating the importance of stem canker of soybean in Iowa. Plant Dis. 94:167-173.

The relative importance of stem canker of soybean in Iowa compared with other soybean diseases present in the state was assessed using data collected from over 3,400 soybean fields sampled in the Iowa Soybean Disease Survey that was conducted from 2005 to 2007. Symptomatic plant tissues from soybean plants with stem canker symptoms were cultured on acidified potato dextrose agar. The prevalence of stem canker on soybean in 2005 in Iowa was 2.6\%; the disease was not detected in 2006 and 2007. In 2005, 63 isolates with Diaporthe/Phomopsis characteristics were collected. To identify isolates to fungal species and variety, single-spored isolates were subjected to polymerase chain reaction-restriction fragment length polymorphism (PCR-RFLP) and sequencing of the internal transcribed spacer (ITS) region. Fourteen isolates were identified as D. phaseolorum var. caulivora (northern stem canker) and 49 as Phomopsis longicolla. To quantify and compare the aggressiveness of D. phaseolorum var. caulivora isolates collected in Iowa, nine isolates were arbitrarily selected for components analysis. Incubation period, rate of lesion expansion, final lesion length, and time to plant death for each isolate were quantified. Significant differences in components of aggressiveness were detected among the nine isolates. Results from this work suggest stem canker is a minor disease of soybean in Iowa.
\end{abstract}

The Diaporthe/Phomopsis pathogen complex is responsible for several diseases of soybean (Glycine max (L.) Merr.): (i) stem canker, which has been divided into northern stem canker caused by Diaporthe phaseolorum var. caulivora, and southern stem canker caused by $D$. phaseolorum var. meridionalis $(6,24)$, (ii) pod and stem blight caused by $D$. phaseolorum var. sojae (anamorph Phomopsis phaseoli), and (iii) seed decay, predominantly caused by Phomopsis longicolla $(23,24)$. These diseases generally occur after flowering in the soybean growing season and can dramatically reduce soybean yield and seed quality (28). Overall, the Diaporthe/Phomopsis complex is thought to cause greater yield losses in soybean than any other single fungal pathogen (28).

Stem canker was first reported in Iowa in the 1940s $(5,27)$. Yield losses of up to $50 \%$ occurred during the 1950 s, and coincided with the time period that farmers were planting cultivars highly susceptible to stem canker (2,3). In 1973, stem canker was reported for the first time in the southern United States (Mississippi) (11), and by 1984 , the disease had been detected throughout the soybean-producing areas of the southern United States (16). Subtle

Corresponding author: A. E. Robertson

E-mail: alisonr@iastate.edu

Accepted for publication 7 October 2009.

doi:10.1094/PDIS-94-2-0167

(C) 2010 The American Phytopathological Society differences in stem canker symptomology were reported for soybeans grown in northern versus southern soybean production areas (3). Furthermore, southern isolates of stem canker differed in cultural characteristics and were reported to be more aggressive than northern isolates (3). Based on these differences, it was proposed that stem canker be subdivided into two diseases: northern stem canker and southern canker. It was further suggested that the causal organisms of these two distinct diseases be recognized as separate forma speciales of $D$. phaseolorum, namely f. sp. caulivora and f. sp. meridionalis, respectively (G. Morgan-Jones, unpublished). Others, however, argued that varietal separation was more appropriate (25). Molecular studies of the two organisms using random amplified polymorphic DNA (RAPD) analyses and phylogenetic analysis of the DNA sequence of the internal transcribed spacer (ITS) supported the proposition that the organisms are varieties of D. phaseolorum $(6,31)$.

Characteristic symptoms of northern stem canker are sunken, dark-brown cankers that first appear on the lower nodes of soybeans (7). Cankers elongate and eventually girdle the stem, leading to plant wilting and death (7). Southern stem canker lesions are more delimited and rarely girdle the stem (7). Similar foliar symptoms, i.e., interveinal chlorosis and necrosis, occur with both stem canker diseases (7), and leaves remain attached to the stem after plant death (4).

Although it was previously assumed that the geographical ranges of northern and southern stem canker did not overlap within the United States and elsewhere (7), both pathogen varieties have since been found to coexist in Illinois (2001) and Wisconsin (2004) $(8,12)$, as well as in Argentina (2001) (20). Since southern stem canker can cause considerable economic damage (3), it is important to verify the presence of this disease in northern soybean producing areas so that appropriate management practices can be implemented in a timely manner. During the 2005, 2006, and 2007 growing seasons, a statewide soybean disease survey (Iowa Soybean Disease Survey) was conducted to assess the relative importance of soybean diseases reported in Iowa. The survey provided the opportunity to re-evaluate the importance of northern stem canker in Iowa soybean production fields over a 3year period. Furthermore, the survey provided a unique opportunity to assess thousands of soybean plants (and fields) for the presence of soybean diseases new to Iowa (e.g., southern stem canker) that could pose a threat to local soybean production.

Traditionally, morphological characteristics of fungal cultures and symptomology on soybeans have been used to differentiate the two fungal varieties causing northern and southern stem canker from one another, as well as from $D$. phaseolorum var. sojae. However, morphological characteristics of isolates within this species can be highly variable and mediadependent, and therefore cannot always be used as reliable criteria for taxonomic classification (31). Moreover, symptoms associated with the development of stem canker or pod and stem blight disease can be easily confused with one another. However, molecular tools may offer a means to reliably differentiate pathogen varieties within the Diaporthe/Phomopsis complex, thereby providing more accurate taxonomic classifications (31). The product of amplification of the ITS region of ribosomal RNA of $D$. phaseolorum with $\mathrm{ITS}_{4}$ and ITS $_{5}$ primers is a 605-bp amplicon (30). Digestion of the 605-bp amplicon with the restriction enzyme AluI has enabled researchers to obtain unique fragment patterns for each pathogen variety, thereby facilitating the ability to accurately differentiate pathogen varieties (31).

To date, isolates of $D$. phaseolorum var. caulivora in Iowa have not been studied for specific components of aggressiveness. Thus, the Iowa Soybean Disease Survey also provided an opportunity to establish a limited baseline on the present status of 
aggressiveness of D. phaseolorum var. caulivora isolates in the state.

The overall goal of this study was to evaluate the importance of stem canker of soybean in Iowa. Data collected as part of the Iowa Soybean Disease Survey afforded us the opportunity to address the following objectives: (i) determine if the causal agent of southern stem canker (D. phaseolorum var. meridionalis) was present in Iowa soybean fields from 2005 to 2007, (ii) assess and map the prevalence and incidence of stem canker and its causal agents in Iowa, and (iii) quantify and compare the aggressiveness of selected Diaporthe phaseolorum var. caulivora isolates collected within Iowa (as part of the disease survey).

\section{MATERIALS AND METHODS}

Sampling. The Iowa Soybean Disease Survey was undertaken during the 2005, 2006, and 2007 soybean growing seasons. Three to 12 soybean fields per Iowa county were randomly selected and sampled by Iowa State University (ISU) Extension Field Agronomists each growing season at four growth stage periods: V2 to V3, R1 to $\mathrm{R} 2, \mathrm{R} 4$ to R5, and R6 to R7, for a total of approximately 900 soybean fields each season. A systematic sampling design (modified cross with $10 \mathrm{arms}$ ) was used to select and collect 30 soybean plants per field (three plants per arm). In addition to the soybean fields that were arbitrarily selected by ISU Extension Field Agronomists, approximately 200 soybean fields each season were selected randomly and sampled each growing season by the United States Department of AgricultureNational Agricultural Statistics Service (USDA-NASS) (17). Therefore, up to 1,200 soybean fields were sampled in each growing season. The fields selected were different in each year of the survey. Soybean plants within USDA-NASS fields were sampled once from late July to late August using a modified W systematic sampling design with 10 arms (three plants per sampling arm and 30 plant samples collected per field). Soybean plant samples collected by both Iowa State University Field Agronomists and USDA-NASS personnel were boxed and shipped overnight to the Department of Plant Pathology, Iowa State University, Ames for disease and pathogen assessments.

Stem canker assessment. Plants from each soybean field were growth staged, and then each leaf on the main stem of each plant was visually inspected for the presence/absence of all plant pathogens/diseases. In addition, each of the main stems was also visually assessed for the presence/absence of external and internal disease symptoms. Since foliar symptoms of stem canker are similar to those of brown stem rot, caused by Cadophora (Phialophora) gregata, and sudden death syndrome (Fusarium virguliformi), extra care was taken to examine the stems of plants with leaves exhibiting interveinal chlorosis and necrosis for the presence of sunken, dark-brown cankers at the lower nodes. In each growing season, the prevalence and incidence of stem canker at both the county and field scale was determined as follows: Stem canker prevalence (\%) was defined as the number of soybean fields (field scale) or Iowa counties (county scale) that had stem canker detected, divided by the total number of soybean fields or counties sampled $\times 100$ (19). Stem canker incidence $(\%)$ was defined as the number of plant stems with stem canker symptoms within a soybean field (field scale) or within an Iowa county (county scale), divided by the total number of stems sampled and assessed per field $(n=$ 30 ) or county $\times 100$ (16). In addition, isolation of the causal organism was attempted from those plant stems with symptoms typical of those associated with stem canker disease. Since Phomopsis spp. were often isolated from stem canker-like symptoms, an additional 32 plants with stem symptoms typical of pod and stem blight from 24 arbitrarily selected fields were collected in order to ascertain if there were any morphological and/or molecular differences associated with the Phomopsis isolates obtained from the two types of disease symptoms.

Spatial analysis. The prevalence and incidence of stem canker at the county scale was mapped using geographic information systems (GIS) software (ArcGIS, ESRI, Redlands, CA). To test the hypothesis that the prevalence and incidence of soybean fields and counties with stem canker occur at random, Moran's Index analysis was used (15). Values for this index can range from -1 to +1 , and positive values indicate that neighboring counties have similar values for the prevalence or incidence of stem canker, i.e., the presence of spatial dependence or clustering.

Isolation and purification of causal organisms. Stems with suspicious symptoms were cut into 2-cm-long sections, surface disinfested in $10 \%$ sodium hypochlorite for $3 \mathrm{~min}$, and then rinsed three times in sterile distilled water (SDW). Stem sections were then partitioned into 5mm-long pieces and placed onto acidified potato dextrose agar (APDA, $\mathrm{pH}=4.5$ ) amended with $0.2 \%$ lactic acid (8). Cultures were incubated in darkness at room temperature $\left(21^{\circ} \mathrm{C}\right)$ for 1 week, and fungal colonies that were typical of Diaporthe or Phomopsis spp. in appearance were transferred onto fresh potato dextrose agar (PDA) and incubated for a minimum of 7 to 10 days under the same conditions as previously described. To induce production of fungal fruiting bodies and spores, cultures were then placed under continuous light at room temperature $\left(21^{\circ} \mathrm{C}\right)$ for 20 to 30 days (14).

Each putative isolate of Diaporthe or Phomopsis spp. was purified using a sin- gle-spore method. Briefly, a $200-\mu l$ sterile pipette tip was used to transfer a pycnidium or perithecium into $1 \mathrm{ml}$ of SDW in a 1.5-ml microfuge tube. The pycnidium/perithecium was crushed using a sterile micropestle to release the spores, after which the spore suspension was mixed thoroughly for $30 \mathrm{~s}$, and then $50 \mu \mathrm{l}$ was transferred to $950 \mu \mathrm{l}$ of SDW. This step was repeated once, and $50 \mu$ of the final suspension $\left(2.5 \times 10^{-3}\right.$ dilution $)$ was uniformly spread onto a 9-cm-diameter petri plate containing PDA using a sterile glass spreader. Dilution plates were incubated in the darkness at room temperature, and after 3 to 5 days, single-spore cultures were transferred to fresh PDA and allowed to incubate at room temperature $\left(21^{\circ} \mathrm{C}\right)$ in darkness for 7 days, followed by 20 days under lights. Based on colony morphological characteristics, purified, sporulating cultures were provisionally identified as either Diaporthe spp. or Phomopsis spp. and stored at $4{ }^{\circ} \mathrm{C}$ for future testing.

Polymerase chain reaction (PCR) amplification and enzymatic digestion. The ITS region of the nuclear rDNA from each purified isolate that had been provisionally identified as Diaporthe or Phomopsis was amplified using ITS $_{4}$ and ITS $_{5}$ primers (30). The protocol used was modified from Zhang et al. (31). Each template DNA was obtained by lightly scraping the leading edge of each 7-day-old fungal colony originating from each single-spore isolate with a sterile pipette tip (10), thus omitting the step involving the extraction of fungal DNA. All PCR tests were performed using a gradient thermal cycler (Mastercycler, Eppendorf, Germany) with a reaction mix of $2.5 \mathrm{mM} \mathrm{MgCl} 2,1 \times$ Coloress GoTaq Flexi Buffer, 0.2 mM PCR nucleotide mix, 50 pmol of primers, and 2.5 units of GoTaq DNA polymerase (Promega Corp., Madison, WI) in a final volume of $50 \mu \mathrm{l}$. Reactions were run for 1 cycle at $96^{\circ} \mathrm{C}$ for $3 \mathrm{~min}$ and 32 cycles each at $94^{\circ} \mathrm{C}$ for $1 \mathrm{~min}, 55^{\circ} \mathrm{C}$ for $1 \mathrm{~min}$, and $72^{\circ} \mathrm{C}$ for $2 \mathrm{~min}$. Amplification efficiency was checked by agarose gel electrophoresis using $5 \mu \mathrm{l}$ of PCR product.

The PCR products of the ITS regions were digested using the restriction enzyme $A l u \mathrm{I}$ according to the manufacturer's protocol (Promega Corp., Madison, WI). Briefly, $2 \mu \mathrm{l}$ of PCR product was digested in a mixture of $2 \mu \mathrm{l}$ of buffer (10x), $0.2 \mu \mathrm{l}$ of acetylated BSA, 5 units of enzyme, and $15.3 \mu \mathrm{l}$ of SDW for $3 \mathrm{~h}$ at $37^{\circ} \mathrm{C}$. Digested products were size-fractionated on $1.5 \%$ agarose at $3.5 \mathrm{~V} / \mathrm{cm}$ and stained with SYBR safe DNA gel stain (Invitrogen Corp., Carlsbad, CA) to enable visualization. A 100-bp double-stranded DNA ladder (Invitrogen) was used as a size marker.

Sequencing. Thirteen isolates of $D$. phaseolorum var. caulivora and 17 isolates of Phomopsis spp. as identified by PCR restriction fragment length polymorphism (RFLP) above, were arbitrarily selected for 
sequencing of the ITS region. The PCR products were purified with QIAquick PCR Purification Kit (Qiagen Inc., Chatsworth, CA). The purified DNA was sequenced on an Applied Biosystems 3730xl DNA Analyzer (Applied Biosystems Division, Perkin-Elmer, Emeryville, CA) using a 4-color dye system that was performed by the Iowa State University DNA Facility. Sequences were checked between complementary strands for reading errors using Sequence Navigator (Applied Biosystems Division, Perkin Elmer, Foster City, CA) and multiple aligned using PAUP*4.0 (Sinauer Associates, Inc., Sunderland, MA).

Components of aggressiveness. Nine isolates of $D$. phaseolorum var. caulivora from different geographic areas of the state were arbitrarily selected to quantify and compare pathogen aggressiveness. Isolate 1 was collected from Plymouth County in northwest Iowa. Isolates 2 and 3 were collected from Monroe and Lee counties, respectively, in southeast Iowa. Isolate 4 was collected from Montgomery County, and isolate 5 was from Mills County, both in southwest Iowa. In northeast Iowa, isolates $6,7,8$, and 9 were collected from Dubuque, Delaware, Clayton, and Winneshiek counties, respectively. Isolates 1,2 , $3,4,5$, and 8 were all isolated from soybean plants exhibiting stem canker symptoms, while isolates 6,7 , and 9 were all isolated from soybean plants exhibiting pod and stem blight symptoms.

Soybean cultivar S35 (Syngenta Seeds, Inc., Golden Valley, MN), which is susceptible to stem canker, was planted in a greenhouse at Iowa State University with temperatures ranging from 23 to $27^{\circ} \mathrm{C}$. At least 1 day prior to inoculation, soybean plants were moved to a growth chamber set at $23^{\circ} \mathrm{C}$ with alternating 12 -h periods of dark and light and a relative humidity of approximately $50 \%$. Soybeans were inoculated with one of the nine isolates of $D$. phaseolorum var. caulivora. Therefore, there were nine treatments, and each treatment was replicated three times. Each replication consisted of three $10-\mathrm{cm}$ diameter pots with four plants in each pot. Assessments for components of aggressiveness for the four plants in each pot were recorded, and the mean value for the four plants within each pot was considered a replication. Plants were inoculated at the V2 to V3 growth stage by inserting a single pathogen-infested toothpick into the stem below the first trifoliate node and sealing the inoculation point with petroleum (11). As a control, three plants were wounded and sealed in the same manner using autoclaved toothpicks.

Four components of aggressiveness were measured to compare isolates: (i) incubation period $(\mathrm{h})$, defined as the time from inoculation to the time when lesion length was $\geq 5 \mathrm{~mm}$; (ii) the rate of lesion expansion, defined as the slope of the re- gression line relating the change in lesion length $(\mathrm{mm})$ on stems with respect to time after inoculation (h); (iii) final lesion length $(\mathrm{mm})$, defined as the length of lesions along the stem at the final measurement time (just prior to plant death); and (iv) time to death (h), defined as the time from inoculation to the time when no green leaf tissue was present. The entire experiment was conducted twice.

To quantify the change in lesion expansion versus time after inoculation, the average lesion length for each isolate at each measurement time was divided by final lesion length for the corresponding isolate. Lesion lengths were measured at 24-h intervals for the first 2 days and then every $12 \mathrm{~h}$ beginning on the third day after inoculation until plant death. These values were plotted with respect to time after inoculation for each isolate (Sigma Plot 10, SPSS Inc., Chicago, IL) and then transformed using linearized growth models (exponential, monomolecular, logistic, and Gompertz) (18). The criteria used to select the best growth model to quantify rates of lesion expansion were the $F$ statistic for the overall model $(P=0.05)$, the coefficient of determination $\left(R^{2}\right)$, the standard error of the estimate for $y\left(\mathrm{SEE}_{y}\right)$, and the visual inspection of residual plots (26). The slope of the regression line for each transformed model was considered to be the rate of lesion expansion for that isolate.

Components of aggressiveness (incubation period, the rate of lesion expansion, final lesion length, and time to death) for each isolate were analyzed using analysis of variance (ANOVA), and mean separations were performed using the WallerDuncan $k$-ratio test $(P=0.05$; Statistical Analysis System 9.1, SAS Institute, Cary, $\mathrm{NC}$ ).

\section{RESULTS}

Weather conditions during the growing season. Weather conditions during each of the 2005 to 2007 growing seasons (typically May through August) varied considerably in each year of the Iowa Soybean Disease Survey (Fig. 1). The 2005 growing season was cooler $\left(14.4^{\circ} \mathrm{C}\right)$ than normal at planting. June was warmer $\left(22.7^{\circ} \mathrm{C}\right)$ with above normal precipitation that was evenly distributed throughout the month, but thereafter rainfall was limited and severe drought occurred in east central and southeast Iowa. Weather conditions at
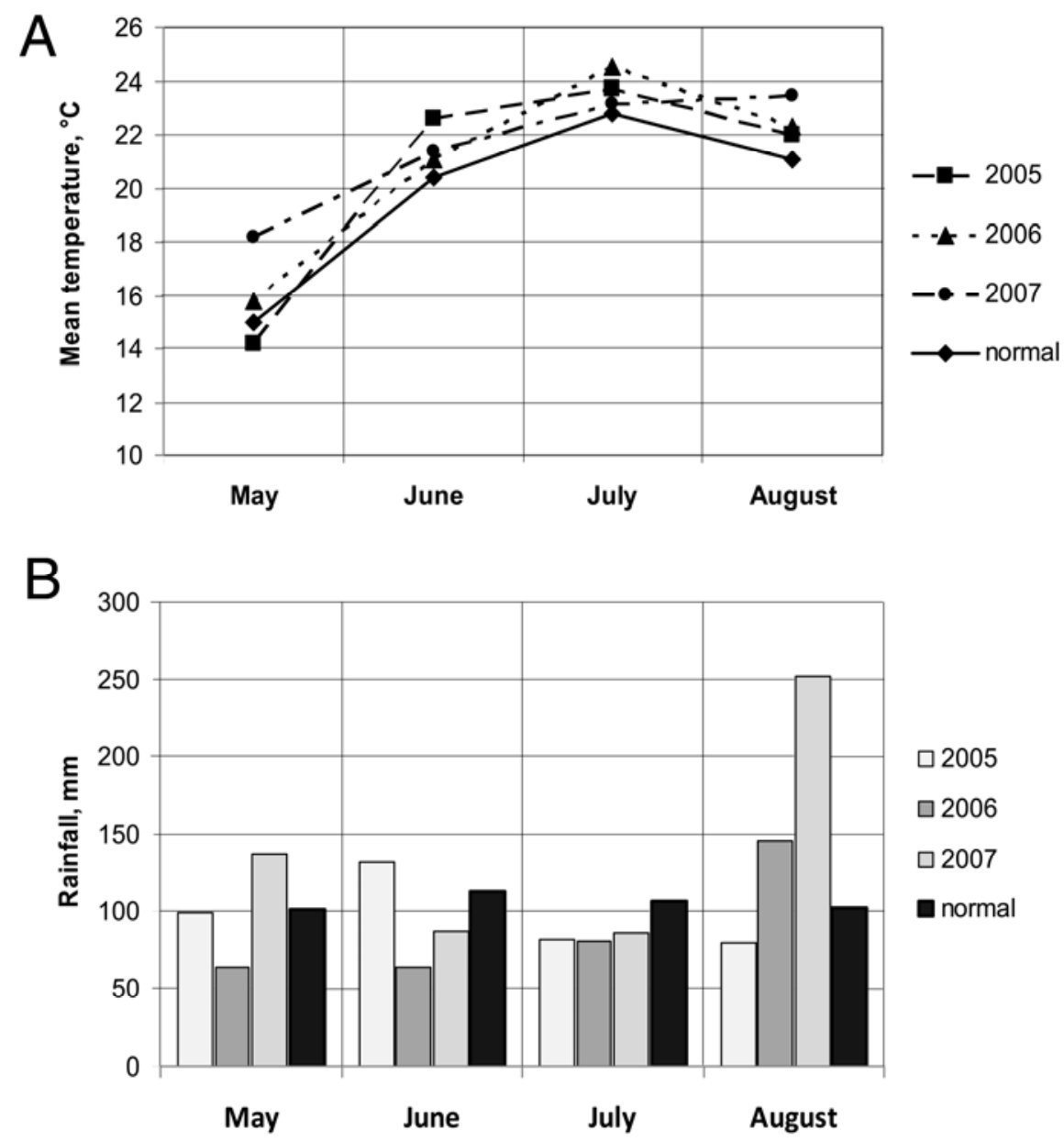

Fig. 1. A, Mean monthly growing season temperatures and B, monthly rainfall totals for the 2005 , 2006, and 2007 growing seasons (May to August) in Iowa compared with normal mean monthly temperature and monthly rainfall totals for the same period, where normal is the 30-year period from 1971 through 2000. 
planting (May) and through June and July of 2006 were warmer $(15.9,21.2$, and $24.6^{\circ} \mathrm{C}$, respectively) and drier than normal. Above-average precipitation occurred in August. Very warm weather $\left(18.3^{\circ} \mathrm{C}\right)$ occurred at planting in 2007, and little precipitation occurred apart from in westcentral and southwestern Iowa, which received flooding rains in the first and third weeks of May. June and July of the 2007 growing season were characterized by warmer and drier than normal conditions, and while August was also warmer, it was considerably wetter than normal.

Stem canker disease prevalence and incidence. Totals of 1,218, 1,068, and 1,096 fields were sampled for stem canker in 2005, 2006, and 2007, respectively, from June to mid-September in each growing season. In 2005, stem canker symptoms were first observed in late July, when the plants were in the R3 growth stage. By the end of the 2005 growing season, 63 soybean plants with sunken dark-brown cankers characteristic of stem canker disease were collected. These symptomatic plants originated from 32 soybean fields representing 26 Iowa counties. Thus, the prevalence of stem canker at the field scale was $2.6 \%$ (32 out of 1,218 soybean fields sampled and assessed) in 2005. Within affected soybean fields, stem canker disease incidence (percentage of plants out of
30 with stem canker symptoms) ranged from 3.3 to $36.7 \%$, with an average incidence of $6.6 \%$. Relative to 21 other soybean diseases reported in Iowa during the 3 -year survey, stem canker ranked 16th in both prevalence and incidence at the field scale in 2005 and last in 2006 and 2007. At the county scale, the prevalence of stem canker ranked 17th out of 21 soybean diseases in 2005, with stem canker occurring in 26 out of 96 counties sampled and assessed $(27.1 \%$ ) (Fig. 2). Stem canker incidence in these counties ranged from 0.2 to $4.3 \%$ (Fig. 2), with an average incidence of $0.6 \%$. Stem canker was not detected in any of the 1,068 and 1,096 fields sampled as part of the Iowa Soybean Disease Survey during the 2006 and 2007 growing seasons, respectively. Moreover, stem canker was not reported to occur in any commercial soybean fields during the 2006 and 2007 growing seasons by well-trained ISU Extension Field Agronomists, and no plant samples with stem canker symptoms were submitted to the Iowa State University Plant and Insect Diagnostic Clinic in those years.

Isolation and identification. In addition to the 63 soybean plants with stem canker symptoms that were collected, 32 plants with pod and stem blight symptoms (growth stages R7 to R8) were also collected. A total of 95 isolates of $\mathrm{Di}$ -
aporthe/Phomopsis were collected from stem canker- and pod and stem blightsymptomatic plants.

Based on the absence/presence of large, irregular black stroma on the underside of the aged cultures, 23 and 72 isolates were provisionally identified as Diaporthe spp. and Phomopsis spp., respectively. Enzymatic digests of the amplified ITS region of each isolate revealed that 19 of the 23 suspected Diaporthe spp. isolates were indeed D. phaseolorum var. caulivora. These isolates originated from 14 of the 63 plants exhibiting stem canker symptoms, and from 5 of the 32 plants showing pod and stem blight symptoms. The remaining four suspected Diaporthe spp. isolates were identified as Phomopsis spp. by digestion of the ITS amplicon of each isolate with Alu1. All 72 isolates provisionally identified as Phomopsis spp. were confirmed to be Phomopsis spp. Thus, isolates of Phomopsis spp. were recovered from 49 plants with stem canker symptoms and 27 plants with pod and stem blight symptoms. It is important to note that we did not isolate $D$. phaseolorum var. meridionalis (the causal organism of southern stem canker) from any of the 63 soybean plants with stem canker symptoms that were collected. Furthermore, we did not find stem canker symptoms on soybean caused by $D$. phaseolorum var. meridionalis in any of

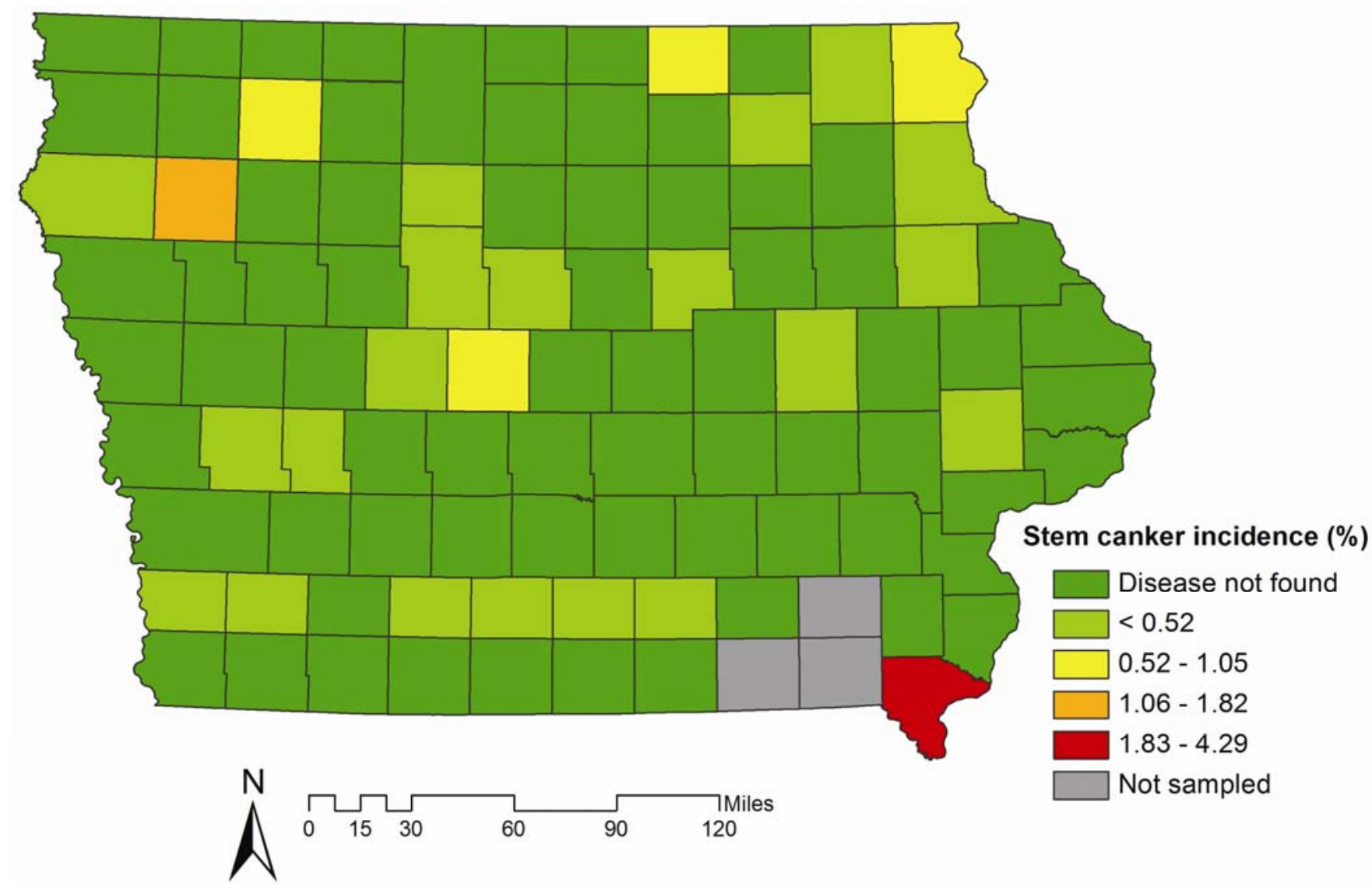

Fig. 2. Incidence of northern stem canker at the county level in 96/99 Iowa counties sampled and assessed in 2005 as part of the Iowa Soybean Disease Survey (A. E. Robertson and F. W. Nutter, Jr., unpublished). There were 1,218 soybean fields sampled and assessed for plants with symptoms of northern stem canker in 2005. Approximately 12 soybean fields were sampled within each Iowa county. 
the approximately 3,400 fields $(\sim 105,000$ plants) sampled and assessed during the 3year survey.

Sequencing. Sequence data of $13 D$. phaseolorum var. caulivora isolates and 17 Phomopsis spp. isolates, as identified by Alu 1 digests of the amplified ITS region, were compared with known sequences in the NCBI nucleotide database. The ITS sequence data confirmed the enzyme digestion results and identified the Phomopsis spp. as $P$. longicolla. No nucleotide differences were observed in the ITS sequences of $D$. phaseolorum var. caulivora isolates from plants with stem canker or pod and stem blight symptoms. Similarly, no nucleotide differences were observed among $P$. longicolla isolates from plants exhibiting either stem canker or pod and stem blight symptoms.

Spatial dependence. Spatial dependence among Iowa counties testing positive for stem canker prevalence was not detected (Moran's I $=0.07, P$ value $=>0.05$ ), indicating a random pattern of counties testing positive for stem canker in 2005. No spatial dependence for stem canker incidence at the field scale was detected either (Moran's I $=0.05, P$ value $=>0.05$ ) .

Components of aggressiveness. Soybean plants inoculated with $D$. phaseolorum var. caulivora using the toothpick method all resulted in infection (100\% infection efficiency for all isolates), and inoculated plants exhibited disease symptoms typical of stem canker. Moreover, $D$. phaseolorum var. caulivora was reisolated from all symptomatic stem tissues. No $D$. phaseolorum var. caulivora or Phomopsis spp. were isolated from controls (inoculated with autoclaved toothpicks).

Incubation period. There were significant differences for the length of the incubation period among the nine isolates $(P<$ 0.0001) (Table 1). Incubation periods ranged from 60 to $96 \mathrm{~h}$, and the nine isolates could be divided into three or four statistically different groups. Isolates 2 and 7 were most aggressive based on the length of the incubation periods, and isolate 1 was least aggressive for this component.

Rate of lesion expansion. The logistic model best fit the lesion expansion data for 11 of the 18 cases (nine isolates $\times$ two experiments) based upon model evaluation criteria. The remaining seven of 18 cases were best described by the exponential model; however, these seven cases also fit the logistic model nearly as well, and therefore the logistic model was chosen as the most appropriate model to quantify and compare the rates of lesion expansion among all nine stem canker isolates. The slope of the regression line using the logistic model for each isolate was considered to be the rate of lesion expansion for each isolate $(\operatorname{logits} / \mathrm{h})$. The rate of lesion expansion was statistically different among the nine isolates $(P<0.0001)$ (Table 1$)$. Based upon the rates of lesion expansion, the most aggressive isolate in both experiments was isolate 4 , and the least aggressive isolate in both experiments was isolate 1 .

Final lesion length. Significant differences were detected among D. phaseolorum var. caulivora isolates for final lesion length $(P<0.0001)$ (Table 1$)$. Isolate 1 showed the most restricted lesion length compared to the other eight isolates, and isolate 5 had the longest final lesion length in both experiments.

Time to death. Time-to-death was found to differ significantly among the nine $D$. phaseolorum var. caulivora isolates $(P<$ 0.0001) (Table 1). Time-to-death ranged from 168 to $240 \mathrm{~h}$, and the nine isolates could be divided into three statistically different groups. Based upon time-todeath, isolates 5 and 7 were the most aggressive, whereas isolates 1 and 3 were the least aggressive in both experiments.

Relationships among components of aggressiveness. Regression analyses conducted for the first experiment revealed that as incubation period increased, timeto-death increased and final lesion length decreased $\left(R^{2}=48.55\right.$ and $55.34 \%$, respectively) (Table 2). Time-to-death also decreased as final lesion length increased $\left(R^{2}\right.$ $=61.14 \%$ ). In addition, time-to-death decreased and final lesion length increased as the rate of lesion expansion increased $\left(R^{2}\right.$ $=43.23$ and $24.3 \%$, respectively). There was no significant relationship between incubation period and the rate of lesion expansion.

\section{DISCUSSION}

This study is the first to comprehensively examine the relative importance of stem canker in Iowa compared to other soybean diseases present in the state. Based on survey results, northern stem canker was ranked 16th out of 21 soybean diseases in 2005 and last in 2006 and 2007 , since the disease was not detected in those growing seasons. Thus, stem canker was found to be a relatively minor disease of soybean in Iowa during the 3-year survey.

There are several possibilities to explain the low prevalence and incidence of northern stem canker during the survey, including resistance, unfavorable environmental conditions for infection and disease development, and the increased use of seed treatments. Based on the results of this survey, the economic importance of this disease was substantially lower from 2005 to 2007 compared to that in the 1950s, when the disease risk for stem canker was much higher. The high disease risk for

Table 1. Analysis and comparison of components of aggressiveness for nine isolates of Diaporthe phaseolorum var. caulivora ${ }^{\mathrm{v}}$

\begin{tabular}{lcccc}
\hline Isolate & $\begin{array}{c}\text { Incubation } \\
\text { period }^{\mathbf{w}}(\mathbf{h})\end{array}$ & $\begin{array}{c}\text { Rate of lesion } \\
\text { expansion }^{\mathbf{x}}\end{array}$ & $\begin{array}{c}\text { Final lesion } \\
\text { length }(\mathbf{m m})\end{array}$ & Time to death $^{\mathbf{y}}(\mathbf{h})$ \\
\hline 1 & $96 \mathrm{a}^{\mathrm{z}}$ & $0.044 \mathrm{e}$ & $24.27 \mathrm{~d}$ & $240 \mathrm{a}$ \\
2 & $60 \mathrm{~d}$ & $0.053 \mathrm{dc}$ & $37.76 \mathrm{a}$ & $192 \mathrm{~b}$ \\
3 & $90 \mathrm{ab}$ & $0.047 \mathrm{de}$ & $31.45 \mathrm{c}$ & $240 \mathrm{a}$ \\
4 & $84 \mathrm{~b}$ & $0.068 \mathrm{a}$ & $35.70 \mathrm{ab}$ & $192 \mathrm{~b}$ \\
5 & $70 \mathrm{c}$ & $0.064 \mathrm{ab}$ & $36.82 \mathrm{ab}$ & $168 \mathrm{c}$ \\
6 & $82 \mathrm{~b}$ & $0.066 \mathrm{a}$ & $34.47 \mathrm{bc}$ & $192 \mathrm{~b}$ \\
7 & $60 \mathrm{~d}$ & $0.057 \mathrm{bc}$ & $36.37 \mathrm{ab}$ & $168 \mathrm{c}$ \\
8 & $86 \mathrm{~b}$ & $0.065 \mathrm{ab}$ & $34.24 \mathrm{bc}$ & $192 \mathrm{~b}$ \\
9 & $84 \mathrm{~b}$ & $0.067 \mathrm{a}$ & $34.87 \mathrm{ab}$ & $192 \mathrm{~b}$ \\
\hline
\end{tabular}

${ }^{\mathrm{v}}$ Soybean plants (Glycine $\max$ 'S35') were wound-inoculated at the node of first trifoliate at the V2V3 growth stage. The experiment was performed twice under controlled conditions in a growth chamber $\left(23^{\circ} \mathrm{C}\right)$ and photoperiod of $12 \mathrm{~h}: 12 \mathrm{~h}$ (data were pooled across two experiments).

${ }^{\mathrm{w}}$ Incubation period was operationally defined as the time from inoculation to the time (h) that lesion length $\geq 5 \mathrm{~mm}$.

${ }^{\mathrm{x}}$ Rate of logit lesion length with respect to time after inoculation (logits/h).

y Plants were considered dead at the time of assessment when no green leaf tissue was present.

${ }^{\mathrm{z}}$ Means with the same letter in the same column are not significantly different $(P=0.05)$.

Table 2. Relationships among components of aggressiveness for nine isolates of Diaporthe phaseolorum var. caulivora on soybean plants (Glycine max 'S35')

\begin{tabular}{|c|c|c|c|c|c|c|}
\hline \multicolumn{2}{|c|}{$\begin{array}{l}\text { Aggressiveness } \\
\text { components }\end{array}$} & \multicolumn{5}{|c|}{ Regression parameters } \\
\hline $\mathbf{X}$ & $\mathbf{Y}$ & $F$ statistic ( $P$ value $)$ & Intercept & Slope & $R^{2}(\%)$ & $\mathbf{S E E}_{y}$ \\
\hline $\mathrm{ip}^{\mathrm{w}}$ & rate $^{x}$ & 0.953 & - & - & - & - \\
\hline ip & $\mathrm{ttd}^{\mathrm{y}}$ & $<0.0001$ & 7.023 & 0.365 & 48.55 & 0.052 \\
\hline ip & $\mathrm{fll}^{\mathrm{z}}$ & $<0.0001$ & 159.089 & -2.35 & 55.34 & 0.293 \\
\hline rate & $\mathrm{ttd}$ & $<0.0001$ & 300.61 & $-1,756.01$ & 43.23 & 279.04 \\
\hline rate & fll & 0.0002 & 21.159 & 218.247 & 24.30 & 53.422 \\
\hline fll & $\mathrm{ttd}$ & $<0.0001$ & 59.57 & -0.129 & 61.14 & 0.014 \\
\hline
\end{tabular}

\footnotetext{
${ }^{\mathrm{w}}$ Incubation period.

${ }^{\mathrm{x}}$ Rate of lesion expansion.

y Time to death.

${ }^{\mathrm{z}}$ Final lesion length.
} 
stem canker in that decade was believed to be associated with the widespread planting of two highly stem canker susceptible soybean cultivars (Hawkeye and Blackhawk) (1). It may be that soybean cultivars now grown in Iowa are moderately resistant to these pathogens. Although cultivar information was recorded for 18 of the 32 fields from which plants with stem canker symptoms were collected, stem canker resistance scores for these cultivars were not available. In Iowa, primarily maturity group 2 and 3 soybeans are planted, and it is rare for seed companies to evaluate and report these maturity groups for stem canker resistance.

Little work has been done on the epidemiology of $D$. phaseolorum var. caulivora. Research done on D. phaseolorum var. meridionalis showed that temperature and wetness periods are important for infection by $D$. phaseolorum var. meridionalis (22), and incidence and severity of southern stem canker is greatest when infection occurs at V3 (4). Northern stem canker disease development is thought to be associated with cooler temperatures and extended periods of rainy, wet weather that occur during the early vegetative growth stages of soybeans. Therefore in Iowa, soybeans are most susceptible to infection by $D$. phaseolorum var. caulivora from late May through June. During our survey, extended periods of rainy weather only occurred in June 2005. In the following 2 years of the survey, growing conditions during the early vegetative stages were drier than normal.

The use of seed treatments on soybean in Iowa is increasing (P. Pedersen, personal communication), and this practice also may have played a role in the low prevalence of stem canker detected in Iowa between 2005 and 2007. In 2005, an estimated total of $28 \%$ of soybean seed was treated with a fungicide. In 2006 and 2007 , approximately 34 and $40 \%$ of seed was treated, respectively. D. phaseolorum var. caulivora is widespread on soybean pods in Iowa (13), and seed infection by the pathogen can be as high as $20 \%$ (7). Xue et al. (29) have reported seed treatments were effective at protecting soybean from seedborne D. phaseolorum var. caulivora and P. longicolla.

Based on the sampling and assessment protocols we used, we did not detect southern stem canker (D. phaseolorum var. meridionalis) in any of the approximately 3,400 soybean fields that were surveyed in Iowa over a 3-year period. There are several alternative weed hosts of D. phaseolorum var. meridionalis $(21,25)$; however, our survey did not include weed hosts. Based on the methods of our survey of 104,842 plants, we can state with a high degree of confidence that southern stem canker of soybean was not found at detectable levels in Iowa during the 3-year Iowa Soybean Disease
Survey. This was somewhat surprising, since southern stem canker has been reported to occur in two neighboring states, Illinois and Wisconsin $(8,12)$. Conversely, we cannot assume that $D$. phaseolorum var. meridionalis is not present in Iowa since we did not include alternate hosts in our survey.

Recovery of more than one of the causal agents involved in the Diaporthel Phomopsis disease complex from plants expressing symptoms typical of northern and southern stem canker, pod and stem blight, and seed decay is not uncommon (24). Moreover, P. longicolla is often recovered more frequently than $D$. phaseolorum var. sojae, which is in turn recovered in higher frequencies than either $D$. phaseolorum var. caulivora or D. phaseolorum var. meridionalis (24). Harrington et al. (9) reported $P$. longicolla was the most frequently isolated fungal pathogen from both discolored and nondiscolored mature soybean stems. In another study, $P$. longicolla was the predominant species isolated from diseased plants collected from nine locations over a 3-year period in Ontario, Canada (29). Similarly, in our study, $P$. longicolla was the predominant fungus isolated from stem canker lesions.

The differentiation of Diaporthe varieties based on morphological characteristics such as color, colony appearance, and size and shape of stromata can be erroneous because these characteristics tend to be extremely variable among pathogen isolates within a variety (25). Moreover, pathogen characteristics within and among pathogen varieties can greatly vary depending on the substrate on which isolates are grown (6). Indeed in our study, we provisionally identified four isolates as $D$. phaseolorum var. caulivora, but PCRRFLP analysis revealed the isolates were actually Phomopsis spp. Our results validated the Zhang et al. method (31) for molecular identification and differentiation of pathogen varieties in the Diaporthel Phomopsis complex.

The Iowa Soybean Disease Survey afforded us the opportunity to collect data on the current level of aggressiveness among isolates of $D$. phaseolorum var. caulivora on a stem canker susceptible line that may be used in future studies on soybean stem canker in Iowa. Comparisons of the components of aggressiveness among the $D$. phaseolorum var. caulivora isolates provided highly repeatable results for both experiments that can serve as a baseline to detect any future shifts in the aggressiveness of this pathogen. Quantitative information concerning the predictive relationships among aggressiveness components also provides new information and methods for use by plant breeders to screen soybean lines for components of resistance (that mirror the components of aggressiveness that we quantified) in the stem canker pathosystem.
ACKNOWLEDGMENTS

We thank the Iowa Soybean Association for funding the Iowa Soybean Disease Survey. We also thank Iowa State University Extension Field Agronomists, personnel from the United States Department of Agriculture, National Agricultural Statistics Service, and all others who assisted us in conducting this 3-year survey. We thank Richard Pope for compiling and charting weather data.

\section{LITERATURE CITED}

1. Athow, K. L. 1987. Fungal diseases. Pages 687-727 in: Soybeans: Improvement, Production and Uses. 2nd ed. J. R. Wilcox, ed. American Society of Agronomy, Madison, WI

2. Athow, K. L., and Caldwell, R. M. 1954. A comparative study of Diaporthe stem canker and pod and stem blight of soybean. Phytopathology 44:319-325.

3. Backman, P. A., Weaver, D. B., and MorganJones, G. 1985 Soybean stem canker: An emerging disease problem. Plant Dis. 69:641648.

4. Bowers, G. R., and Russin, J. S. 1999. Soybean disease management. In: Soybean Production in the Mid-south. L. G. Heatherly and H. F. Hodges, eds. CRC Press, Boca Raton, FL.

5. Crall, J. M. 1950. Soybean diseases in Iowa in 1949. Plant Dis. Rep. 34:96-97.

6. Fernandez, F. A., and Hanlin, R. T. 1996 Morphological and RAPD analyses of $\mathrm{Di}$ aporthe phaseolorum from soybean. Mycologia 88:425-440.

7. Fernandez, F. A., Phillips, D. V., Russin, J. S. and Rupe, J. C. 1999. Stem Canker. Pages 33 35 in: Compendium of Soybean Diseases. G L. Hartman, J. B. Sinclair, and J. C. Rupe, eds. American Phytopathological Society, St. Paul, $\mathrm{MN}$.

8. Gravert, C. E., Li, S., and Hartman, G. L. 2001. Occurrence of Diaporthe phaseolorum var. meridionalis on soybean in Illinois. Plant Dis. $85: 1211$.

9. Harrington, T. C., Steimel, J., Workneh, F., and Yang, X. B. 2000. Molecular identification of fungi associated with vascular discoloration of soybean in the north central United States. Plant Dis. 84:83-89.

10. Harrington, T. C., and Wingfield, B. D. 1995 A PCR-based identification method for species of Armillaria. Mycologia 87:280-288.

11. Keeling, B. L. 1982. A seedling test for resistance to soybean stem canker caused by $D i$ aporthe phaseolorum var caulivora. Phytopathology 72:807-809.

12. Li, S., Kurtzweil, N. C., Grau, C. R., and Hartman, G. L. 2004. Occurrence of soybean stem canker (Diaporthe phaseolorum var. meridionalis) in Wisconsin. Plant Dis. 88:576.

13. McGee, D. C., and Biddle, J. A. 1987. Seedborne Diaporthe phaseolorum var. caulivora in Iowa and its relationship to soybean stem canker in the southern United States. Plant Dis. 71:620-622.

14. Mengistu, A., Castlebury, L. A., Smith, J. R., Rossman, A. Y., and Reddy, K. N. 2007. Isolates of Diaporthe-Phomopsis from weeds and their effect on soybean. Can. J. Plant Pathol. 29:283-289.

15. Moran, P. A. P. 1950. Notes on continuous scholastic phenomena. Biometrika 37:17-23.

16. Mulrooney, R. P. 1985. Soybean disease loss estimate for southern United States in 1983. Plant Dis. 69:92.

17. Neher, D. A., and Campbell, C. L. 1996. Sampling for regional monitoring of nematode communities in agricultural soils. J. Nematol. 28:196-208.

18. Nutter, F. W., Jr. 1997. Quantifying the temporal dynamics of plant virus epidemics: A review. Crop Prot. 16:603-618.

19. Nutter, F. W., Jr. 2001. Disease assessment terms and concepts. Pages 312-323 in: Ency- 
clopedia of Plant Pathology. O. C. Maloy and T. D. Murray, eds. John Wiley and Sons, New York.

20. Pioli, R. N., Morandi, E. N., and Bisaro, V. 2001. First report of soybean stem canker caused by Diaporthe phaseolorum var. caulivora in Argentina. Plant Dis. 85:95.

21. Roy, K. W., Miller, W. A., and McLean, K. S. 1994. Survey of pathogenic genera of fungi on foliage of weeds in Mississippi. Can. J. Plant Pathol.-Revue Canadienne De Phytopathologie $16: 25-29$.

22. Rupe, J. C., Sutton, E. A., Becton, C. M., and Gbur, E. E. 1996. Effect of temperature and wetness period on recovery of the southern biotype of Diaporthe phaseolorum var. caulivora from soybean. Plant Dis. 80:255-257.

23. Sinclair, J. B. 1988. Diaporthe/Phomopsis complex of soybeans. Pages 96-101 in: Soybean Diseases of the North Central Region. T. D. Wyllie and D. H. Scott, eds. American Phytopathological Society, St. Paul, MN.
24. Sinclair, J. B. 1999. Diaporthe-Phomopsis Complex. Pages 31-32 in: Compendium of Soybean Diseases. J. B. Sinclair, G. L. Hartman, and J. C. Rupe, eds. American Phytopathological Society, St. Paul, MN.

25. Smith, E. F., and Backman, P. A. 1988. Soybean stem canker: An overview. Pages 47-55 in: Soybean Diseases of the North Central Region. T. D. Whyllie and D. H. Scott, eds. American Phytopathological Society, St. Paul, $\mathrm{MN}$.

26. Webb, D. H. and Nutter, F. W., Jr. 1997. Effects of leaf wetness duration and temperature on infection efficiency, latent period, and rate of pustule appearance of rust in alfalfa. Phytopathology 87:946-950.

27. Welch, A. W., and Gilman, J. C. 1948. HeteroThallic and Homo-Thallic Types of Diaporthe on Soybeans. Phytopathology 38:628-637.

28. Wrather, J. A., Anderson, T. R., Arsyad, D. M. Gai, J., Ploper, L. D., PortaPuglia, A., Ram, H. H., and Yorinori, J. T. 1997 Soybean disease loss estimates for the top 10 soybean producing countries in 1994. Plant Dis. 81:107-110.

29. Xue, A. G., Morrison, M. J., Cober, E., Anderson, T. R., Rioux, S., Ablett, G. R., Rajcan, I, Hall, R., and Zhang, J. X. 2007. Frequency of isolation of species of Diaporthe and Phomopsis from soybean plants in Ontario and benefits of seed treatments. Can. J. Plant Pathol.-Revue Canadienne De Phytopathologie 29:354-364.

30. Zhang, A. W., Hartman, G. L., Riccioni, L., Chen, W. D., Ma, R. Z., and Pedersen, W. L. 1997. Using PCR to distinguish Diaporthe phaseolorum and Phomopsis longicolla from other soybean fungal pathogens and to detect them in soybean tissues. Plant Dis. 81:11431149.

31. Zhang, A. W., Riccioni, L., Pedersen, W. L., Kollipara, K. P., and Hartman, G. L. 1998. Molecular identification and phylogenetic grouping of Diaporthe phaseolorum and Phomopsi longicolla isolates from soybean. Phytopathology 88:1306-1314. 